\title{
Penerapan Pendidikan Kristen Konteks Keluarga Dalam Menanamkan Karakter Jujur Pada Anak Di TK Kristen Petra Terpadu
} Natalia

Sekolah Tinggi Agama Kristen Terpadu Pesat Salatiga nataliapangalayo97@gmail.com

\author{
Ahmad Tabrani \\ Sekolah Tinggi Agama Kristen Terpadu Pesat \\ ahmadstakpesat@gmail.com
}

Article History
Submit:
October $14^{\text {th }}, 2021$
Revised:
November $1^{\text {st }}, 2019$
Published:
December13
rd, 2021

Abstrak:

Pendidkan Kristen dalam konteks keluarga sangat penting untuk dilakukan karena keluarga adalah wadah yang dibentuk Allah untuk seorang anak diohadirkan agar dididik dalam pengenalan akan Allah dan bertumbuh dalam karakter. Karakter jujur sangat penting ditanamkan dan dibentuk dalam diri anak. Karena kejujuran akan menjadi modal utama bagi seseorang untuk dapat dipercaya oleh orang lain. Kepercayaan yang akan menjadi dasar bagi hubungan sosial baik yang bersifat kekeluargaan, persahabatan maupun dalam hubungan kerja atau usaha. Penelitian ini menggunakan jenis penelitian kualitatif melalui wawancara orang tua anak TK A yaitu delapan informan keluarga yang beragama Kristen. Metode pengumpulan data menggunakan wawancara. Hasil penelitian menemukan bahwa, Pendidikan Kristen konteks keluarga di TK Kristen Petra Terpadu belum diterapkan oleh semua keluarga. Dari delapan keluarga yang menjadi responden, hanya terdapat dua keluarga yang masuk dalam kategori sangat baik dalam menerapkan pendidikan kristen dalam keluarga. Sedangkan enam keluarga lain dinilai masih kurang dalam menerapkan pendidikan Kristen dalam keluarga. Hasil penelitian kepada delapan anak TK A Kristen Terpadu Petra menunjukkan bahwa sebagian kecil anak (dua orang) menunjukkan karaker jujur dalam kategori baik dan sebagian besar (enam anak) kurang menunjukkan karakter jujur. Hasil penelitian juga menunjukkan bahwa keluarga yang menerapkan pendidikan kristen dalam keluarga dengan sangat baik memiliki anak yang menunjukkan karakter jujur sangat baik, Sedangkan keluarga yang kurang baik dalam menerapkan pendidikan kristen dalam keluarga memiliki anak yang kurang baik dalam menunjukkan karakter jujur dalam diri anak. Hal ini menunjukkan bahwa pendidikan kristen dalam keluarga memberikan dampak bagi terbentuknya karakter jujur dalam diri anak. Dimana faktor keteladanan orangtua dalam perkataan dan perbuatan menjadi faktor yang sangat menentukan pembentukan karakter jujur 
http://jurnalsttn.ac.id/index.php/SJT p-ISSN 2772-3078, e-ISSN 2772-306X
Sekolah Tinggi Teologi Nusantara, Salatiga

Edisi: Volume 2, Nomor 2, November 2021

pada diri anak.

Kata-kata kunci: Pendidikan Kristen, Keluarga, Karakter Jujur, Anak

Abstract:

Christian education in the context of the family is very important to do because the family is a place formed by God for a child to be brought up to be educated in the knowledge of God and grow in character. Honest character is very important to be instilled and formed in children. Because honesty will be the main capital for someone to be trusted by others. Trust that will be the basis for social relations, whether family, friendship or in work or business relationships. This study uses a qualitative type of research through interviews with parents of TK A children, namely eight family informants who are Christian. Methods of data collection using interviews. The results of the study found that family context Christian education in Petra Terpadu Christian Kindergarten had not been implemented by all families. Of the eight families who were respondents, there were only two families that were categorized as very good in implementing Christian education in the family. Meanwhile, the other six families were considered to be lacking in implementing Christian education in the family. The results of the study on eight children of Petra Integrated Christian Kindergarten A showed that a small number of children showed honest character in the good category and most (six children) did not show honest character. The results also show that families who apply Christian education in the family show a very good honest character, while families who are not good at implementing Christian education in the family show honest character in their children. This shows that Christian education in the family has an impact on the formation of honest characters in children. Where is the exemplary factor of parents in quotes and factors of action that really determine the honest character of the child.

Keywords: Christian Education, Family, Honest Character, Children.

\section{Pendahuluan}

Pendidikan merupakan salah satu bagian terpenting dalam kehidupan manusia. Selanjutnya pendidikan dapat dipandang sebagai suatu proses pemberdayaan dan pembudayaan individu agar mampu memenuhi kebutuhan perkembangannya dan sekaligus memenuhi tuntutan sosial, kultural, dan religius dalam lingkungan kehidupannya (FIP-UPI, 2007, p. hal.95). Proses pendidikan dapat terjadi di mana saja, seperti sekolah, rumah atau lingkungan masyarakat, yang 
berguna yang dapat menghasilkan perubahan pada diri seseorang yang dilakukan secara sadar dan terencana, kemudian menggerakkan pikiran, perbuatan, dan pengalaman, serta ada perubahan pengetahuan, sikap, dan keterampilan seseorang.

Harianto mengatakan bahwa keluarga merupakan lembaga pertama pendidikan yang Allah tetapkan di bumi (GP, 2012, p. hal.69). Allah mendirikan keluarga agar anak belajar dari orang tua. Sebelum membentuk jemaat dan pemerintah, Allah memberkati pernikahan dan keluarga sebagai dasar masyarakat. Tidak ada tempat yang lebih baik dan penting untuk menumbuhkan iman, dan menaburkan nilai-nilai kristiani selain keluarga. Hal yang hampir sama juga dikatakan oleh Samuel Sijabat dalam bukunya mengatakan bahwa keluargalah yang merupakan pelaku dan sekaligus lingkungan primer bagi pembentukan watak, tata nilai dan disiplin anak sebelum memasuki usia sekolah, dan dunia masyarakat (Sijabat, 1994, p. hal.63). Dengan melihat hal tersebut, keluarga memiliki arti yang sangat penting dan utama dalam mendidik anak yang Tuhan hadirkan kepada orang tua, sehingga anak tersebut bertumbuh dalam pengenalan kebenaran Firman Tuhan dan memiliki kepribadian yang sesuai dengan kebenaran Firman Tuhan yang menjadi dasar dan pedoman dalam setiap langkah kehidupan anak yang lebih baik.

Pendidikan Kristen selalu menuju kepada ajaran tentang kebenaran firman Tuhan yang bertindak sebagai orang Kristen dan berlaku baik sesuai ajaran firman Tuhan yang diterima dari pendidikan Kristen. Sehingga terwujud kehidupan yang bermakna, damai, dan bermartabat. Anak akan diarahkan baik atau jahat tergantung pada orang tua (Hapudin, 2019, p. hal.12). Keluarga merupakan lingkungan pendidikan yang paling dekat dengan anak, kontribusi lingkungan keluarga mestinya memberikan dampak yang positif dalam hidup anak, terutama orang tua yang sangat berpengaruh terhadap kesuksesan penerapan pendidikan kristen dalam konteks keluarga yang seharusnya cukup berpengaruh besar dalam hidup anak. Mestinya hasil dari pendidikan yang orang tua berikan akan ada hasil karakter yang baik ditanamkan anak. Didukung dari pernyataan Ida Harefa dan Ahmad Tabrani salah satu aspek yang berperan dalam pembentukan karakter anak adalah keluarga 
(Harefa \& Tabrani, 2021). Sangatlah mendasar bahwa keluarga menjadi peran utaman dalam menanamkan karakter bagi anak.

Rida Sinaga menyatakan bahwa kewajiban orang-orang percaya untuk mendidik anak-anak agar hidup sesuai dengan firman Tuhan dengan membentuk anak-anak yang berkarakter kristiani (R. Sinaga, 2018). Karakter seseorang yang positif atau mulia akan menjadikan setatus derajat yang tinggi dan mulia bagi dirinya (Zubaedi, 2011, p. hal.6). Batasan ini menunjukkan bahwa karakter sebagai identitas seseorang dalam nilai kehidupan yang bersifat menetap sehingga berbeda dengan yang lain dalam perilaku. Salah satu nilai karakter yang sangat penting dalam kehidupan adalah kejujuran, yang merupakan tingakah laku seorang individu dalam mengakui, berkata atau memberikan suatu informasi yang sesuai dengan kenyataan dan kebenaran (Hutami, 2020, p. hal.14).

Oleh karena itu, nilai karakter jujur merupakan sikap ataupun prilaku seseorang yang senantiasa dapat dipercaya dengan apa yang diucapkan dengan apa yang ada dalam hatinya sehingga seseorang tersebut dapat dipercayai, serta memiliki kepribadian maupun akhlak yang baik. Karena kejujuran akan tercermin dalam dalam prilaku, yang dapat dilihat dari cara berbicara apakah sesuai dengan kenyataan, atau berbuat sesuai bukti dan kebenrarannya.

Tokoh Alkitab Elkana dan Hana menunjukkan sikap dan peran orang tua dalam menanamkan nilai-nilai kekristenan kepada anaknya Samuel yakni sikap taat kepada Allah dan mempersiapkan Samuel untuk bisa melayani Tuhan (Prabowo, 2020). Selama Elkana dan Hana dipercayakan untuk menerima berkat Tuhan yang mereka nanttikan, keduanya mengajarkan Samuel tentang nilai-nilai Kekristenan sehingga Samuel mengenal Allah yang disembah oleh orang tuanya. Keluarga Kristen yang telah ditebus oleh darah Yesus Kristus dan percaya kepada-Nya harus berperan dalam penerapan pendidikan Kristen. Menanamkan karakter jujur pada anak sejak usia dini dengan tujuan mencerdaskan bangsa yang takut akan Tuhan dan berakhlak mulia di hadapan Tuhan dan masyarakat. 
Situasi pandemic Covid 19 menyebabkan seluruh sekolah menerapkan proses belajar di rumah. Hal ini juga terjadi pada proses pendidikan di TK Kristen Petra Terpadu yang berkedudukan di Kelurahan Tambangan, Kecamatan Mijen Kotamadya Semarang, Jawa Tengah. Berdasarkan situasi yang dihadapi dan berlandaskan Surat Edaran Mendikbud No. 4 tahun 2020, maka diterapkan proses belajar dari rumah (learn from home) bagi anak-anak sekolah. TK Kristen Petra Terpadu. Hal ini menyebabkan proses pembelajaran banyak bergantung kepada tingkat partisipasi orangtua dalam proses pembelajaran anak didik.

Dalam keadaan seperti ini, peran orang tua untuk pendidikan anak sangat penting dilakukan secara efektif di rumah. Bagi orang tua TK A yang anaknya baru masuk dunia pendidikan sangatlah penting untuk menanamkan karakter jujur pada anak. Orang tua menerapkan pendidikan Krsiten konteks keluarga dalam menanamkan karakter jujur anak. Orang tua memiliki waktu lebih banyak dengan anak di masa pandemik Covid-19. Orang tua bukan hanya mendampingi anak mengerjakan tugas dari guru, berupa tugas-tugas lembaran kertas, buku, dan bentuk video, tetapi kesempatan bagi orang tua TK A yang beragama Kristen mengajarkan nilai-nilai kekristenan untuk menanamkan karakter jujur pada anak. Seperti: menyampaikan Injil kepada anak, mengenalkan Alkitab sejak dini, mengenalkan cara berdoa, membiasakan anak beribadah, memberikan teladan dalam perkataan dan perbuatan, membangun kasih di dalam diri anak. Ketika ini semua ditanamkan sejak usia dini akan menghasilkan buah karakter jujur anak yang lebih baik. Anak selalu berkata benar dan apa adanya, mau mengakui kesalahan, tidak menipu atau mencuri, mendorong orang lain melakukan kebenaran, tidak memutarbalikan fakta.

Dengan masalah di atas mendorong dilakukannya penelitian lebih jauh tentang penerapan pendidikan Kristen dalam menanamkan karakter jujur pada anak. Penelitian dilakukan kepada para orangtua yang beragama Kristen dari murid Kelas A pada TK Kristen Petra Terpadu. Penelitian dilakukan dengan tujuan untuk mendapatkan gambaran bagaimana penerapan Pendidikan Kristen konteks keluarga dalam menanamkan karakter jujur pada Kelas A di TK Kristen Petra Terpadu". 


\section{Metode Penelitian}

Metode penelitian dalam penulisan karya ilmiah adalah metode penelitian kualitatif. Bogdan dan Taylor menjelaskan bahwa penelitian kualitatif adalah prosedur penelitian yang menghasilkan data deskriptif berupa kata-kata tertulis atau lisan dari orang-orang dan perilaku yang dapat diamati (Suwendra, 2018, p. Hal. 4). Selanjutnya, Informan dalam penelitian ini tertuju kepada orang tua anak kelompok TK A yang beragama Kristen yang terdiri dari delapan keluarga di TK Kristen Petra Terpadu. Adapun dua variabel penelitian yakni Pendidikan Kristen dalam konteks keluarga dan Karakter Jujur. Indikator dari variabel Pendidikan Kristen dalam keluarga yaitu menyampaikan Injil kepada anak, mengenalkan Alkitab sejak dini, mengenalkan cara berdoa, membiasakan anak beribadah, menjadi teladan dalam perkataan dan perbuatan dan membangun kasih dalam diri anak. Indikator dari penelitian variabel karakter jujur anak yaitu selalu berkata benar dan apa adanya, mengakui kesalahan, tidak berbohong dan mencuri, mendorong orang lain melakukan kebenaran dan tidak memutarbalikan fakta.

\section{Hasil Dan Pembahasan}

\section{Pendidikan Kristen Konteks Keluarga}

Pendidikan Kristen adalah "pendidikan yang Kristen" dengan kata lain adalah pendidikan yang bercorak, berdasar dan berorientasi Kristiani (Sidjabat, 1996, p. hal.27). Hal ini berarti bahwa dogma iman Kristen harus menjadi dasar pendidikan Kristen. Tujuan Pendidikan Kristen harus sesuai dengan tujuan Allah bagi umat-Nya seperti yang disampaikan dalam Firman Tuhan. Pendidikan Kristen menurut Robert W. Pazmino adalah usaha-usaha manusia dan Ilahi yang bertujuan, sistematis, dan teruji waktu untuk membagikan pengetahuan, nilai, sikap, keterampilan, kepekaan, dan tingkah laku yang konsisten dengan iman Kristen (Robet W. Pazmino, 2011, p. hal.119). Kembali ditekankan bahwa iman Kristen harus menjadi dasar dan tujuan bagi strategi dan proses pendidikkan yang 
dilakukan. Selain itu, Werner C. Graendorf mendefinisikan pendidikan Kristen demikian: untuk membimbing individu-individu pada semua tingkat perkembangannya dengan cara pendidikan kontemporer menuju pengalaman dan pengalaman akan tujuan serta rencana Allah dalam Kristus melalui setiap aspek kehidupan dan juga untuk pelayanan yang efektif (Hasudungan Simatupang. et.al, 2020, p. hal.52). pendapat ini menekankan bahwa tujuan akhir dari Pendidikan Kristen adalah membawa peserta didik untuk berkontribusi dalam pelayanan sesuai panggilannya sebagai buah dari pemahaman dan pengalamannya akan tujuan dan rencana Allah. Dimana kasih kepada Allah dinyatakan dalam perbuatan nyata bagi sesama. Hal lain dikatakan oleh Samuel Sidjabat pendidikan Kristen adalah unik, karena dasar, sifat, fokus dan dinamikanya. Karena pemikiran mengenai dasar, arah, isi, dan dinamika pendidikan bersumber dari ajaran Alkitab (Sidjabat, 1996). Pemahaman terhadap Alkitab sebagai sumber utama Pendidikan Kristen akan memberi pengaruh besar terhadap tujuan, isi dan proses Pendidikan Kristen ditetapkan dan dilakukan.

Dari berbagai pendapat diatas dapat kita lihat bahwa Pendidikan Kristen yang bersumber dari ajaran Alkitab yang bertujuan untuk membagikan pengetahuan, nilai, sikap, keterampilan, kepekaan, dan tingkah laku yang konsisten dengan iman Kristen. Sehingga pada waktunya peserta didik dapat mengaktualisasikan kasihnya kepada Allah dalam berbagai bentuk pelayanan kepada sesama sebagai wujud aktualisasi dirinya untuk menggenapi tujuan penciptaan Allah atas dirinya. Melihat pendapat para ahli diatas, maka Pendidikan Kristen harus dimulai dalam keluarga dimana peserta didik untuk pertama kali dihadirkan ke dunia. Karena Pendidikan agama Kristen dalam keluarga bukan hanya mengajarkan pengetahuan agama Kristen, tetapi keluarga juga dapat menanamkan keteladanan dan praktek hidup toleran yang dasarnya cinta kasih Yesus Kristus yang sudah rela berkorban di salib untuk menebus dosa manusia (yonatan alex arifianto, 2020, p. hal.94-106). Kitab Ulangan pasal 6 merupakan perintah Tuhan kepada orang tua agar mengajar anak-anaknya untuk mengenal Allah: siapa Allah itu dan mengasihi-Nya dengan sepenuhnya, melalui segala 
aspek kehidupan. Perintah itu disertai dengan pengajaran. Ia memerintah agar mengajarkannya secara berulang-ulang, di mana saja, kapan saja, dan dengan segenap kemampuan, termasuk menjadi teladan. Ditekankan dalam kitab Ulangan 6:4-9 "Dengarlah, hai orang Israel: TUHAN itu Allah kita, Tuhan itu esa! Kasihilah TUHAN, Allahmu, dengan segenap hatimu dan dengan segenap jiwamu dan dengan segenap kekuatanmu. Apa yang kuperintahkan kepadamu hari ini haruslah engkau perhatikan, haruslah engkau mengajarkannya berulang-ulang kepada anak-anakmu dan membicarakannyaapabila engkau duduk di rumahmu, apabila engkau berbaring dan apabila engkau bangun. Haruslah juga engkau mengikatkannya sebagai tanda pada tanganmu dan haruslah itu menjadi lambang di dahimu, dan haruslah engkau menuliskannya pada tiang pintu rumahmu dan pada pintu gerbangmu". Nats dalam kitab Ulangan ini menegaskan bahwa memahami, mengalami dan mengasihi Allah yang Esa harus dialami dan oleh anak-anak dalam keluarga. Pendidikan Kristen dalam keluarga bertujuan untuk anak-anak sebagai peserta didik mengenal Allah dan mengasihi Alah. Orangtua sebagai pendidik, terutama ayah, harus mnengajarkan pengetahuan kepada anak-anaknya sekaligus memberi teladan kehidupan yang nyata. Dimana peserta didik dapat melihat, "menangkap" dan menyerap dalam dirinya melalui kehidupan sehari-hari bagaimana orangtuanya mengasihi Allah. Kasih kepada Allah yang terlihaat dari cara berpikir orangtuanya; kasih kepada Allah yang menjadi dasar pekerjaan tangan yang dilakukan orangtuanya; kasih kepada Allah yang menjadi dasar bagaimana orangtua membangun dan menata kehidupan keluarga, kasih kepada Allah yang menjadi dasar bagaimana orangtuanya membangun kehidupan sosial di tengah masyarakat.

Penanggung jawab utama dalam mendidik adalah orang tua. Karena Pendidikan harus dimulai dari keluarga (Kej.18:19; Ul.6:7; Ams.22:6) (khoe yao tung, 2015, p. hal.40). Tuhan telah memberikan tanggung jawab utama kepada orang tua untuk mendidik anak dan bertanggung jawab atas masa depan dan perkembangan anaknya. Anak memerlukan kasih dan perhatian yang terus menerus, dan ini hanya dapat diberikan oleh orang tua bukan orang lain. 
Keluarga adalah lingkungan hidup yang pertama bagi setiap orang dan memberi pengaruh kuat bagaimana seseorang berusaha memenuhi kebutuhan dasarnya, mendapatkan pengetahuan, memiliki sikap dan mengembangkan keterampilan yang diperlukannya. Dalam keluarga seorang anak mengalami pembentukan karakter, dimana moralitas untuk membedakan baik, buruk, benar dan salah, etis dan tidak etis diperkenalkan pertama-tama dalam keluarga(Halmawati, 2017, p. hal. 34). Keluarga Kristen adalah persekutuan hidup antara ayah, ibu, dan anakanak yang telah percaya dan menerima Yesus Kristus sebagai Tuhan dan Juruselamat secara pribadi serta meneladani hidup dan ajaran-ajaran -Nya dalam kehidupan sehari-hari . Penekanan kepada kehidupan keluarga yang menerima dan menjadikan Yesus sebagai Tuhan dan Juruselamat menjadi penting sebagai dasar utama identitas iman Kristen dalam sebuah keluarga.

Keluarga menduduki posisi penting dalam Alkitab oleh karena Allah ternyata tidak mengadakan perjanjian dengan individu, melainkan dengan satu umat yang terdiri dari orang tua dengan anak-anaknya (Riemer, 2006, p. hal.12). Dalam iman Kristen, keluarga sangat penting karena hubungan khusus Allah dan umat-Nya dimaksudkan untuk dilaksanakan melalui keluarga (Novalia, 2020). Allah merencanakan keluarga dalam dunia untuk menggenapi dan menikmati janji Allah. Keluarga adalah suatu nilai dan pembentuk nilai kehidupan. Allah telah menciptakan manusia dengan kebutuhan-kebutuhan tertentu yang hanya dapat dipenuhi melalui keluarga. Dalam keluarga tersedia rasa aman, naungan, perlindungan, pemeliharaan, rasa kasih sayang, pengakuan sebagai bagian suatu kelompok tanpa syarat. Keluarga merupakan suatu lingkungan belajar, dimana anak menjadi dewasa melalui keluarga.

Pendidikan Agama Kristen dalam keluarga merupakan hal yang penting karena merupakan dasar dari seluruh pendidikan lainnya (Tong, 2012, p. hal.99). Keluarga merupakan wadah paling pontesial untuk menanamkan iman yang kokoh dan pembentukan karakter (Nuhamara, 2007, p. hal.50). Jika keluarga menjadi kokoh dan kuat, maka keluarga sebagai unit terkecil menjadi dasar pembentukan masyarakat dan bangsa yang kuat dan gereja yang sejati. 
Keluarga Kristen harus mengupayakan pertumbuhan rohani bukan saja menyangkut iman dan pengetahuan tentang Allah, tetapi menyangkut kualitas anak-anak dalam menghadapi tantangan zaman (Novalia, n.d.). Keluarga harus memampukan anak-anak berpikir kritis sehingga dapat menganalisa dan menolak berbagai pemikiran yang bertentangan dengan iman Kristen. Anak dalam keluarga Kristen harus dididik untuk berpikir kritis sehingga mampu mempertahankan iman di tengah-tengah arus hidup yang tidak mencerminkan murid Kristus. Selain itu dalam keluarga harus ada ikatan kasih yang kuat, saling menopang, saling menolong, dimana orang tua menjadi teladan hidup bagi anaknya.

Pendidikan Kristen dalam keluarga mengupayakan perubahan, pembaharuan anggota keluarga secara pribadi, maupun bersama oleh Roh Kudus sehingga keluarga hidup sesuai dengan kehendak Allah yang dinyatakan melalui Alkitab (Dien Sumiyatiningsih, 2017, p. hal.15). Sehingga dalam keluarga berlangsung proses pendidikan yang utama dan bersifat kodrati.

Hal-hal penting yang harus ada dalam proses pendidikan Kristen konteks keluarga adalah pertama menyampaikan Injil kepada anak; Penginjilan adalah penyampaian Kabar Baik bagi orang, atas yang telah diperbuat Allah didalam dan melalui Yesus Kristus, bagi kepentingan pengampunan dosa-dosa manusia serta penebusannya (1 Kor. 15: 3-4) (Sijabat, 1994, p. hal.162). Setiap anak membutuhkan penebusan Allah melalui darah Yesus Kristus. Maksudnya, bahwa anak juga memerlukan berita injil yang dapat memberikan keyakinan pengampunan dosa dan keselamatan. Anak adalah seorang pribadi yang unik, "anak adalah pribadi yang matang dalam pemandangannya sendiri". Artinya, anak memiliki potensi untuk mengerti, memahami, dan menerima suatu perkara sesuai dengan tingkat perkembangannya. Karena itu, anak membutuhkan penjelasan berita injil yang sesuai dengan tingkat pengertiannya, sejajar dengan kemampuan bahasa yang dimiliki anak. Seorang anak dilahirkan membawa "gambar dan rupa" orang tuanya (Kej. 5:3). Sehingga anak tidak mungkin lepas dari sifat-sifat baik dan buruk yang ada pada orang tuanya. Dengan kata lain anak telah membawa tabiat dosa di dalam dirinya. Jadi anak sangatlah membutuhkan karya pengorbanan Yesus Kristus. Anak memiliki 
dimensi rohani yang tetap hampa apabila tidak dipuaskan oleh kehadiran Roh Sang Pencipta alam semesta. Sebab, Roh sajalah yang mampu memberikan damai dan ketentraman batin, serta keyakinan akan pengampunan dosa yang diterima dari Allah. Seorang anak dapat menerima kehadiran Roh Kudus, anak pun harus mendengar dan menerima berita Injil Yesus Kristus.

Kedua, mengenalkan Alkitab sejak dini. Alkitab adalah kebenaran. Tidak adak kata cukup untuk mengetahui informasi dalam Alkitab. Richards menegaskan Alkitab harus diajarkan kepada anak sehingga anak mengetahui isi yang dikatakan Alkitab (K. M. Sinaga, 2021). Allah menggunakan Alkitab untuk mengubah kehidupan manusia, termasuk juga anak-anak. Sehingga perbuatannya semakin berubah sesuai dengan pengajaran Alkitab. Dengan kata lain, Alkitab mengubah kehidupan manusia, maka Alkitab harus diajarkan supaya anak mengalami perjumpaan dengan Sang Firman. Alkitab adalah Firman Allah, kebenaran-kebenarannya harus dialami oleh anak. Mengajar Alkitab kepada anak berarti menerjemahkan kebenaran Firman ke dalam tahapan-tahapan yang dapat dialami oleh anak. Menerjemahkan inti kebenaran Alkitab ke dalam pemikiran dan kegiatan yang akan menolong anak mengalami kenyataan yang diajarkan sehingga bukan hanya sekedar nasihat moral.

Ketiga, mengenalkan cara berdoa. Doa adalah komunikasi setiap orang kepada Tuhan (Djumetan et al., 2020). Dalam komunikasi tersebut akan ada hubungan timbal balik, yakni ada suatu percakapan antara Allah dan umat-Nya, berarti doa merupakan percakapan, dalam doa akan menghasilkan pengalaman spiritual yang dalam. Mazmur 25:14 “Tuhan bergaul karib dengan orang yang takut akan Dia, dan perjanjian-Nya diberitahukan-Nya kepada mereka."Sangat penting untuk menolong seorang anak memiliki hubungan pribadi dengan Tuhan, melatih mereka berbicara dengan Tuhan dan belajar "mendengarkan" getaran hati Tuhan. Kehidupan doa seorang anak akan mencegah kehidupan duniawi dan mengarahkannya kepada hal-hal yang dikehendaki oleh Tuhan. Melalui doa seorang anak belajar memiliki Satu Pribadi yang sangat mengasihinya. Orang tua 
harus menjadi teladan doa yang baik bagi anak-anaknya. Orang tua yang berdoa akan dilihat dan ditiru oleh anak.

Ke-empat, membiasakan anak beribadah. Membiasakan anak beribadah adalah suatu yang sangat penting. Seorang anak hendaknya dibiasakan untuk bangun pagi untuk mengikuti ibadah. Tanamkan pada anak bahwa ibadah bersama baik dalam keluarga maupun Bersama orang percaya lainnya adalah kehendak Tuhan dan menyenangkan hati Tuhan. Ibadah dalam persekutuan orang percaya akan membentuk komunitas dalam hidup anak-anak. Dalam komunitas tersebut seorang anak akan belajar mengasihi, berbuat baik dan belajar menghadapi berbagai masalah sosial. Kelima menjadi teladan di dalam perkataan dan perbuatan. Orang tua hendaknya memberikan contoh dalam setiap perkataan, perbuatan, dengan sopan, ramah, saling menghargai, tidak menentang dan adil antara suami dan istri, orang tua dan anak, keluarga dan orang lain. Seorang anak sangat mudah meniru perkataan dan perbuatan yang dilakukan orang tua. Karena itu berkata-kata dan bertindaklah dengan penuh hikmat Tuhan. Ke-enam membangun kasih di dalam diri anak. Kasih adalah hukum Tuhan yang utama. Alkitab mencatat mengasihi Allah dan sesama adalah hukum yanag utama. Penting bagi seorang anak untuk belajar mengasihi Tuhan dan sesama. Mereka akan meneladani tindakan kasih dari orang tua.

\section{Karakter Jujur Anak}

Setiap anak harus diajar untuk mengetahui dan mengikuti kebenaran, Karena hal ini akan memengaruhi setiap aspek kehidupannya (Siswanto, 2013, p. hal.77). Mereka harus diajar dan latih untuk berpikir benar, berbicara kebenaran dan bertindak dengan benar. Setiap keputusan, kata-kata yang diucapkan oleh anak dan sikapnya menjadi dasar hubungan anak dengan orang lain. Seseorang dianggap jujur jika selalu memberikan fakta-fakta yang sebenarnya. Kejujuran adalah tindakan kekal, bukan hanya sementara. Orang tua harus selalu membangun karakter jujur dalam diri anaknya. Karena ketika seorang anak memiliki karakter jujur, maka ia dapat dipercaya orang lain. Kepercayaan harus menjadi dasar bagaimana seorang anak membangun hubungan dengan orang lain. 
Karena itu sangat penting untuk menanamkan karakter jujur melalui pengajaran kebenaran Firman Tuhan dalam diri anak, Penanaman karakter jujur pada anak itu sangat penting dilakukan untuk bisa membentuk masa depan generasi penerus bangsa yang jujur dan tidak menyimpang dalam kehidupan diri sendiri maupun dalam kehidupan lingkungan sekitarnya. Dalam proses ini, keteladan dari seorang guru dan orang tua sangat penting.

"Jujur" berarti tidak berdusta. Kejujuan adalah dasar utama kepercayaan yang menentukan hubungan seseorang dengan orang lain (Nababan, 2019). Kata kejujuran juga diartikan sebagai perbuatan mengakui atau mengatakan segala informasi sesuai dengan kebenaran dan kenyataannya. Kejujuran adalah berbicara kebenaran apa adanya atau mengatakan hal yang benar, penuh ketulusan atau tidak menyanjung orang agar suka kepada diri sendiri atau berpikir baik tentang diri sendiri, dan memiliki sikap yang dapat dipercaya artinya berjanji dan tepat waktu, serta mengakuinya dan tidak mencari-cari alasan. Jujur jika diartikan secara baku adalah mengakui, berkata atau memberikan suatu informasi yang sesuai dengan kenyataan dan kebenaran (Lewis, 2004, p. hal.201-207). Dalam Kamus Bahasa Indonesia jujur adalah tidak berbohong; berkata sebenarnya; tidak curang; lurus hati (Indonesia \& Perbankan, 2014, p. hal.310).

Dari pengertian di atas disimpulkan bahwa karakter jujur merupakan dasar utama hubungan kepercayaan seseorang dengan orang lain sebagai perbuatan mengakui atau mengatakan segala informasi sesuai dengan kebenaran dan kenyataannya atau mengatakan apa adanya mengenai satu hal yang benar, penuh ketulusan atau tidak menyanjung dari kebenaran, serta mengakuinya dan tidak mencari-cari alasan untuk membenarkan diri.

Ciri-ciri orang yang memiliki kejujuran yaitu tidak berbohong, tidak mengingkar janji, tidak menipu, serta mengakui kesalahan merupakan dasar pegangan dalam berbuat jujur (Hutami, 2020, p. hal.16). Dalam hal ini, untuk mewujudkannya dibutuhkan peran orang tua dalam menanamkan karakter jujur pada anak. Jika kejujuran sudah ditanamkan sejak dini dalam keluarga maka karakter jujur dapat tertanam dalam diri anak. Nilai karakter kejujuran adalah 
sikap ataupun perilaku seseorang yang senantiasa dapat menyesuaikan antara yang diucapkan dengan yang di hati sehingga dapat dipercayai. Kepercayaan adalah hadiah kejujuran. Adapun yang menjadi indikator kejujuran anak adalah : pertama selalu berkata benar dan apa adanya; artinya, anak berani mengatakan kebenaran walupun sulit. Berkata benar akan menunjukan keberanian dan ketulusan dari seorang anak yang berkarakter jujur. Kedua mau mengakui kesalahan; artinya, anak bersedia mengakui kesalahan yang telah dilakukan oleh anak. Mengakui sesuatu yang salah akan memperlihatkan jati diri anak yang berkarakter jujur. Ketiga tidak menipu atau mencuri; artinya, jika mencuri atau menipu anak akan merasa tidak nyaman atas yang dilakukan dan dikatakan; ke-empat mendorong orang lain melakukan kebenaran; artinya, seorang anak dapat menjadi teladan dalam melakukan kebenaran, sehingga mendorong temannya untuk melakukan hal yang sama. anak yang jujur adalah anak yang dapat dipercaya dan dihormati oleh lingkungannya. Kelima, tidak mau memutarbalikkan fakta; artinya, anak tidak membuat hal yang salah menjadi benar, atau sebaliknya.

Peran orang tua dalam menanamkan karakter jujur pada anak adalah memberikan pengertian dan teladan kejujuran dalam kehidupan. Keluarga menjadi tempat pertama bagi anak untuk mengenal belajar lingkungannya serta menjadi tempat tumbuh-kembang karakter dalam diri anak. Jika orang tua berlaku jujur, anak tentu akan meniru orang tuanya. Begitu juga sebaliknya, anak akan meniru ketidakjujuran saat orang tua berlaku tidak jujur kepada anaknya atau orang lain dilihat dan didengar oleh anak sehingga anak dapat melakukan yang sudah dilihat dan dilakukan oleh lingkungannya. Dalam hal ini, ada beberapa hal yang bisa dilakukan orang tua dalam penanaman karakter jujur kepada anaknya; Pertama, tumbuhkan kesadaran bahwa berbohong adalah hal yang sangat berbahaya. Jelaskan secara detail dan berikan contoh nyata dalam kehidupan sehari-hari yang dapat dilihat dan dipahami anak. Kedua, jangan sungkan untuk meminta maaf pada anak jika orang tua berbuat salah, lupa dengan janji yang telah dibuat. Ketiga, jawab pertanyaan anak dengan benar dan apa adanya. Beri jawaban sesuai dengan tahap perkembangan anak. Keempat, berikan perhatian dan pengawasan yang 
cukup pada anak. Perhatian dan pengawasan memiliki peran penting dalam membentuk kepribadian anak. Tentu saja tanpa membuat anak merasa selalu diamat-amati oleh orang tuanya, dalam arti orang tua memberi batas dalam mengawasi anak, dengan tidak memberikan didikan yang otoriter. Kelima, orang tua bisa membacakan buku yang menceritakan perilaku jujur, kemudian mendiskusikan pemahaman tentang jujur kepada anaknya, mengapa harus jujur, contoh perilaku jujur dan tidak jujur, bagaimana jika ada teman yang tidak jujur?, ini bisa menolong untuk anak memahami lebih dalam tentang karakter jujur. Keenam, orang tua menerapka sikap jujur saat bermain, belajar, berinteraksi. Agar itu menjadi kebiasaan anak saat berada dilingungan luar. Dengan cara menghargai sikap jujur anak yang ditunjukkan anak dengan cara menguatkan melalui kalimat, misalnya: "terima kasih kamu sudah jujur" (Hutami, 2020, p. hal.37-38).

Pembentukan karakter anak sangat membutuhkan kasih. Kasih yang benar harus disertai dengan disiplin yang sesungguhnya. Penerapan disiplin memiliki beberapa faktor, yaitu : pertama faktor pengarahan, disiplin mengandung arti pengarahan akan hal-hal yang benar dalan salah. Pembentukan karakter berdasarkan pondasi Alkitab yang menyatakan kepada apa yang benar dan apa yang salah dan mengarahkan perilaku sesuai dengan firman Tuhan. Kedua faktor pengendalian, disiplin juga berarti pengendalian diri. Manusia dilahirkan dalam dosa, maka terlihat benih-benih atau tabiat dosa dalam diri anak. Karena itu orang tua harus menolong anaknya untuk mengendalikan diri dengan melibatkan campur tangan Tuhan, sehingga jiwa anak diubah menuju hidup baru dalam Kristus. Ketiga faktor konsistensi, disiplin harus dijalankan dengan konsisten. Konsisten antara suami dan istri dalam mendidik anak sangatlah menolong anak untuk tetap konsisten antara perkataan dan tindakan, sehingga tidak menciptakan karakter yang tidak jujur dalam diri anak, mana yang dikatakan tidak sesuai denga apa yang sebenarnya terjadi. Ke-empat faktor punishment atau pemberian sanksi, disiplin kadang-kadang juga memiliki pengertian pemberian sanksi sebagai konsekuensi atas kesalahan yang telah dilakukan. Namun hal ini hendaknya 
didahului dengan pengertian dan kesepakatan bersama mengenai konsekuensi yang didapat seorang anak Ketika dia melakukan hal yang salah. Namun orangtua juga harus mengajar anak untuk pertama-tama menyadari, mengakui mengakui kesalahan dan memohon ampun kepada Tuhan. Pemberian sanksi hendaknya dilaakukan dalam kasih sehingga anak mengerti dan tidak memiliki akar pahit dengan orang tua.

\section{Hasil Penelitian}

\section{Pendidikan Kristen dalam konteks keluarga}

Penelitian dilakukan kepada delapan keluarga Kristen dimana anak mereka bersekolah di TK Kristen Terpadu Petra. Mengingat situasi pandemik covid 19 yang dialami maka peneliti tidak dapat melakukan pengematan kepada para responden. Karena itu pengumpulan data dilakukan melalui wawancara dengan menggunakan alat komunikasi jarak jauh. Dengan menggunakan enam indikator pendidikan Kristen dalam konteks keluarga, yaitu (1) menyampaikan Injil kepada anak, (2) mengenalkan Alkitab sejak dini, (3) mengenalkan cara berdoa, (4) membiasakan anak beribadah, (5) menjadi teladan dalam perkataan dan perbuatan, (6) membangun kasih dalam diri anak. Melalui wawancara didapatkan gambaran bahwa dari 8 responden, hanya terdapat satu keluarga yang melakukan keenam indikator tersebut meskipun mereka mengaku belum melakukannya setiap hari atau setiap dengan sangat baik. Terdapat satu keluarga yang melakukan 5 dari 6 indikator dimana penginjilam kepada anak belum mereka lakukan. Keluarga ini menyatakan bahwa biasanya ibu guru di TK atau gurtu sekolah mingu yang menyampaikan Injil kepada anaknya. Menurut mereka, guru TK atau Guru sekolah minggu jauh lebh baik dalam menyampaikan Injil kepada anak disbanding orangtua. Empat responden hanya melakukan tiga dari enam indikator. Satu responden hanya melakukan 2 dari 6 indikator dan satu responden hanya melakukan satu indikator.

Dari delapan responden, hanya satu keluarga yang telah menyampaikan Injil kepada anaknya dan membimbing anak untuk menerima Yesus sebagai Tuhan dan juruselamat pribadi. Empat keluarga mengaku telah memperkenalkan Alkitab sejak 
dini kepada anak-anaknya dengan menyampaikan cerita-cerita Alkitab atau membacakan Alkitab kepada anak-anaknya. Sedangkan empat responden lainnya mengaku belum memperkenalkan Alkitab kepada anak-anaknya. Seluuh responden mengaku telah mengenalkan cara berdoa kepada anak-anaknya mellaui doa makan dan doa sebelum tidur. Lima rsponden telah membiasaka anak beribadah terutama ibadah di gereja. Hanya dua responden berani menyatakan bahwa telah berusaha menjadi teladan dalam perkataan dan perbuatan kepada anak-anaknya. Sedangkan enam responden lain menyatakan bahwa mereka belum menjadi teladan bagi anakanaknya dalam perkataan dan perbuatan. Enam responden menyatakan telah berusaha membangun kasih dalam diri anak, dengan mengajari untuk berbuat baik kepada saudara dan temannya.

Dari hasil wawancara kepada delapan keluarga, dapat disimpulkan bahwa hanya satu keluarga yang telah menerapkan pendidikan Kristen konteks keluarga dengan sangat baik dengan melakukan enam indikator pendidikan Kristen dalam keluarga. Satu keluarga yang melakukan 5 indikator juga dapat dikategorikan telah melakukan Pendidikan konteks keluarga dengan sangat baik. Meskipun belum menyampaikan Injil kepada anaknya, namun mereka menganggap hal itu penting dan mengharapkan sekolah dan gereja yang melakukan bagi anaknya. Empat rsponden dapat dikatakan cukup dalam melakukan Pendidikan Kristen bagi anakanaknya karena melakukan tiga dari enam indikator. Sedangkan dua responden dapat dikatakan sangat kurang dalam melakukan Pendidikan Kristen dalam keluarga mereka.

Dalam bentuk tabal, hasil wawancara dapat digambarkan sebagai berikut :

Tabel 1. Pendidikan Kristen dalam konteks keluarga :

\begin{tabular}{|l|l|l|l|l|l|l|l|l|}
\hline \multirow{2}{*}{ No } & \multirow{2}{*}{ Resp } & \multicolumn{4}{|l|}{ Indikator } & \multicolumn{6}{l|}{ Ket } \\
\cline { 3 - 9 } & & $\mathbf{1}$ & $\mathbf{2}$ & $\mathbf{3}$ & $\mathbf{4}$ & $\mathbf{5}$ & $\mathbf{6}$ & \\
\hline 1 & R1 & $\checkmark$ & $\checkmark$ & $\checkmark$ & $\checkmark$ & $\checkmark$ & $\checkmark$ & Sangat Baik \\
\hline 2 & R2 & $\times$ & $\checkmark$ & $\checkmark$ & $\checkmark$ & $\checkmark$ & $\checkmark$ & Sangat Baik \\
\hline 3 & R3 & $\times$ & $\times$ & $\checkmark$ & $\times$ & $\times$ & $\times$ & Sangat \\
\hline
\end{tabular}




\begin{tabular}{|l|l|l|l|l|l|l|l|l|}
\hline & & & & & & & & Kurang \\
\hline 4 & R4 & $\times$ & $\times$ & $\checkmark$ & $\checkmark$ & $\times$ & $\checkmark$ & Kurang \\
\hline 5 & R5 & $\times$ & $\checkmark$ & $\checkmark$ & $\times$ & $\times$ & $\checkmark$ & Kurang \\
\hline 6 & R6 & $\times$ & $\times$ & $\checkmark$ & $\checkmark$ & $\times$ & $\checkmark$ & Kurang \\
\hline 7 & R7 & $\times$ & $\checkmark$ & $\checkmark$ & $\times$ & $\times$ & $\checkmark$ & Kurang \\
\hline 8 & R8 & $\times$ & $\times$ & $\checkmark$ & $\checkmark$ & $\times$ & $\times$ & Sangat \\
& & & & & & & & Kurang \\
\hline
\end{tabular}

\section{Karakter Jujur Anak}

Dalam menilai karekter jujur anak, peneliti menggunakan 5 kriteria, yaitu : (1) selalu berkata benar dan apa adanya, (2) mau mengakui kesalahan, (3) tidak berbohong atau mencuri, (4) mendorong orang lain melakukan yang benar, (5) tidak memutarbalikkan fakta. Hanya satu responden yang menyatakan bahwa anaknya memenuhi lima kristeria karakter jujur, meskipun mengaku anaknya pernah berbohong namun kemudian mengakuinya dan berjanji tidak melakukannya lagi. Satu responden menyatakan anaknya memiliki karakter jujur karena memenuhi kriteria, namun beberapa kali masih berbohong. Satu responden menilai anaknya kadang jujur kadang tidak jujur, dan dari 5 kriteria jujur, anaknya memenuhi tiga kriteria, dimana anaknya masih sering berbohong dan beberapa kali tidak menyampaikan hal yang tidak sesuai fakta sebenarnya. Satu responden menyatakan bahwa anaknya kurang jujur karena masih sering tidak bicara apa adanya, sering berbohong, dan suka memutarbalikkan fakta. Hanya dua kriteria yang terpenuhi yaitu berani mengakui kesalahan dan mendorong kakanya untuk berkata jujur. Tiga responden mengaku anaknya sangat kurang dalam hal kejujuran. Hanya satu kriteria yaitu mendorong orang lain untuk berbuat benar yang terpenuhi dalam diri anaknya. Satu responden lain mengaku bahwa tidak satupun kriteria terpenuhi dalam diri anaknya. Mereka mengakui anaknya memiliki karakter jujur yang sangat buruk.

Dalam bentuk tabel, hasil wawancara dapat digambarkan sebagai berikut : 
Tabel 2. karakter jujur pada anak

\begin{tabular}{|l|l|l|l|l|l|l|l|}
\hline \multirow{2}{*}{ No } & \multirow{2}{*}{$\operatorname{Resp}$} & \multicolumn{4}{|l|}{ Indikator } & \multicolumn{4}{l|}{ Ket } \\
\cline { 3 - 8 } & & $\mathbf{1}$ & $\mathbf{2}$ & $\mathbf{3}$ & $\mathbf{4}$ & $\mathbf{5}$ & \\
\hline 1 & R1 & $\checkmark$ & $\checkmark$ & $\checkmark$ & $\checkmark$ & $\checkmark$ & Sangat Baik \\
\hline 2 & R2 & $\checkmark$ & $\checkmark$ & $\times$ & $\checkmark$ & $\checkmark$ & Sangat Baik \\
\hline 3 & R3 & $\times$ & $\times$ & $\times$ & $\checkmark$ & $\times$ & Kurang Baik \\
\hline 4 & R4 & $\times$ & $\times$ & $\times$ & $\checkmark$ & $\times$ & Kurang Baik \\
\hline 5 & R5 & $\checkmark$ & $\checkmark$ & $\times$ & $\checkmark$ & $\times$ & Cukup \\
\hline 6 & R6 & $\times$ & $\times$ & $\times$ & $\times$ & $\times$ & Sangat kurang \\
\hline 7 & R7 & $\times$ & $\times$ & $\times$ & $\checkmark$ & $\times$ & Kurang baik \\
\hline 8 & R8 & $\times$ & $\checkmark$ & $\times$ & $\checkmark$ & $\times$ & Kurang baik \\
\hline
\end{tabular}

Dari perbandingan keluarga yang melakukan pendidkan Kristen dalam keluarga dan gambaran karakter jujur pada anak, dapat dilihat bahwa anak yang memiliki karakter jujur ternyata berasal dari keluarga yang menerapkan pendidikan Kristen dalam keluarga. Sedangkan anak yang memiliki karakter jujur yang dinilai kurang juga berasal dari keluarga yang kurang dalam menerapkan Pendidikan Kristen dalam keluarga. Dari hasil wawancara yang terlihat dalam tabel, maka faktor memberi teladan dalam perkataan dan perbuatan menjadi factor sangat penting. Mengingat keluarga yang mengaku tidak menjadi teladan dalam perkataan dan perbuatan bagi anak-anaknya ternyata memiliki anak-anak dengan karakter jujur yang sangat kurang bahkan buruk meskipun telah melakukan tiga dari enam indikator Pendidikan Kristen dalam keluarga.

\section{Kesimpulan}

Berdasarkan hasil penelitian yang dilakukan pada orang tua murid TK A yang beragama Krsiten bahwa Pendidikan Kristen konteks keluarga di TK Kristen Petra Terpadu belum diterapkan oleh semua keluarga. Dari delapan keluarga hanya terdapat dua keluarga yang masuk dalam kategori sangat baik dalam menerapkan pendidikan kristen dalam keluarga. Selebihnya dinilai masih kurang dalam menerapkan pendidikan Kristen dalam keluarga.. Hasil penelitian juga 
menunjukkan bahwa keluarga yang menerapkan pendidikan kristen dalam keluarga dengan cukup baik memiliki anak yang menunjukkan karakter jujur dengan baik, sedangkan keluarga yang kurang dalam menerapkan pendidikan kristen dalam keluarga memiliki anak yang kurang dalam menunjukkan karakter jujur dalam diri anaknya. Hal ini menunjukkan bahwa pendidikan kristen dalam keluarga memberikan dampak bagi terbentuknya karakter jujur dalam diri anak. Dimana keteladanan orangtua dalam perkataan dan perbuatan menjadi factor yang sangat menentukan terbentuknya karakter jujur pada anak. 


\section{Daftar Rujukan}

Dien Sumiyatiningsih, S. (2017). Pendidikan Agama Kristen Dan Budi Pekerti.

Djumetan, D., Teologi, S. T., Arastamar, I., \& Selatan, N. (2020). Kehidupan Doa dan Penyembahan dalam Kehidupan Spiritual. ERESI: Jurnal Teologi Dan Pendidikan Kristen, 1(2), 109. https:/ / www.sttia-nisel.ac.id/e-journal/index.php/eresi

FIP-UPI, T. P. I. P. (2007). Ilmu E Aplikasi Pendidikan. PT. Imperial Bhakti Utama.

GP, H. (2012). Pendidikan Agama Kristen Dalam Alkitab Dan Dunia Masa Kini. Andi.

Halmawati. (2017). Pendidikan Karakter Sehari-Hari.

Hapudin, M. S. (2019). Membentuk Karakter Baik Pada Diri Anak. Tazkia Press.

Harefa, I. D., \& Tabrani, A. (2021). Problematika Pendidikan Karakter, Antara Konsep dan Realita. SHAMAYIM: Jurnal Teologi Dan Pendidikan Kristiani. https://doi.org/10.51615/sha.v1i2.23

Hasudungan Simatupang. et.al. (2020). Pengantar Pendidikan Agama Kristen. Andi.

Hutami, D. (2020). Pendidikan Karakter Kebangsaan Untuk Anak Jujur dan Bertanggung Jawab.

Indonesia, K. B. B., \& Perbankan, M. O. (2014). Jakarta: Penerbit PT Gramedia Pustaka Utama.

khoe yao tung. (2015). menuju sekolah kristen impian masa kini. Andi.

Lewis, B. A. (2004). Character bulding. Karisma publishing group.

Nababan, D. (2019). Keluarga Kristen sebagai Keluarga Allah. JHC: Jurnal Christian Humaniora, 3(1), 1-10.

Novalia, L. (n.d.). PHRONESIS: Jurnal Teologi Dan Misi. 2020, 3(1), 104-117.

Novalia, L. (2020). INTEGRASI KONTEKS PENDIDIKAN AGAMA KRISTEN 
KEDALAM PELAKSANAAN PEMBELAJARAN. Phronesis Jurnal Teologi Dan Misi, 3(1), 104-117. https:// doi.org/10.47457/phr.v3i1.53

Nuhamara, D. (2007). Pembimbing Pendidikan Agama Kristen.

Prabowo, W. (2020). Peran Elkana dan Hana terhadap Masa Kecil Samuel: Tahap Awal Mencetak Pemimpin Kristen. EDULEAD: Journal of Christian Education and Leadership, 1(2), 162-179. https:/ / doi.org/10.47530/edulead.v1i2.39

Riemer, G. (2006). Ajarlah Mereka Melakukan.

Robet W. Pazmino. (2011). fondasi pendidikan kristen. PT.BPK.Gunung Mulia.

Sidjabat, B. S. (1996). Strategi Pendidikan Kristen. Andi.

Sijabat, S. (1994). Strategi Pendidikan Kristen. Andi.

Sinaga, K. M. (2021). Konsep Pendidikan Anak Menurut Lawrence O. Richards dan Implementasi bagi Perkembangan Iman Anak Dalam Keluarga Kristen. Mitra Sriwijaya: Jurnal Teologi Dan Pendidikan Kristen, 1(2), 23-38. https://doi.org/10.46974/ms.v1i2.23

Sinaga, R. (2018). Pendidikan Karakter pada Anak Usia Dini. Societas Dei: Jurnal Agama Dan Masyarakat. https:// doi.org/10.33550/sd.v5i2.89

Siswanto, I. (2013). Character Building For Kid (Membangun Karakter Anak). ANDI.

Suwendra, W. (2018). Metologi Penelitian Kualitatif.

Tong, S. (2012). Keluarga Bahagia.

yonatan alex arifianto. (2020). pentingnya pendidikan kristen dalam membangunkerohanian keluarga di masa pandemik covid-19. vol.5.

Zubaedi. (2011). Desain Pendidikan Karakter. Kencana. 